\title{
Epilepsy and developmental disorders: Next generation sequencing in the clinic
}

Introduction:

Over the past 20 years there have been rapid advances in our understanding of the genetic causes, contributors, and modifiers of most human diseases. Epilepsy has been no exception. It has long been appreciated that epilepsy has strong genetic determinants, a concept supported by evidence from twin-based heritability studies ${ }^{1,2}$, and from the observation that epilepsy is a common feature of a number of genetic multisystem disorders, such as tuberous sclerosis complex (TSC) ${ }^{3}$, fragile Xsyndrome ${ }^{4}$, DiGeorge syndrome ${ }^{5}$ and Angelman syndrome ${ }^{6}$. By the early 1990 s, the molecular genetic basis of many of these multisystem disorders was beginning to be understood.

\section{The channelopathy era:}

In 1995 Steinlein et al. identified a rare variant in the CHRNA4 gene, encoding the alpha 4 subunit of the neuronal nicotinic acetylcholine receptor ${ }^{7}$. This variant segregated with affected individuals within a large family affected by autosomal dominant nocturnal frontal lobe epilepsy (ADNFLE), originally reported by Scheffer et $\mathrm{al}^{8}$. The discovery of CHRNA4 was a significant breakthrough on two counts. First, the families affected by ADNFLE demonstrated no additional medical or cognitive morbidity in addition to their epilepsy, so this was heralded as the first "pure epilepsy" gene. Second, this discovery implicated neuronal ion channels in the aetiology of epilepsy for the first time. A pattern of ion channel gene association with epilepsy continued with the subsequent discoveries that $70-80 \%$ of children with Dravet syndrome had variants in the sodium channel gene $S C N 1 A^{9-12}$, and that variants in the potassium channel genes ${ }^{13}$ and $K C N Q 3^{14}$ were associated with self-limited familial neonatal seizures.

\section{The Next Generation Sequencing (NGS) era:}

Since 2005, the development and application of high throughput genetic testing has facilitated the discovery of hundreds of epilepsy-associated genes. As of 2017 at least 66 different epilepsyassociated ion channel genes had been published. However, ion channel genes in fact constitute a minority of the total. Genes involved in diverse cellular processes are now known to be implicated in epilepsy. Such processes can be broadly divided into: ion transport; cell growth and differentiation; regulation of synaptic processes; transport and metabolism of small molecules within and between cells; and regulation of gene transcription and translation (Figure 1).

High throughput genetic testing platforms, including epilepsy gene panels, clinical exome sequencing, and whole exome sequencing, have now entered the clinical domain and are being applied to increasing numbers of patients with epilepsy. In this review, we provide an overview of the current landscape of genetic testing in childhood epilepsies, including the yield of different testing approaches and the impact of a genetic diagnosis on patient management.

\section{Parallel epilepsy gene discovery paths:}

Studies aimed at identifying associations with epilepsy can be broadly divided into two categories: 1 . those comparing large cohorts of patients with epilepsy with healthy controls which look for enrichment of common genetic variants among those with epilepsy - known as genome wide association studies (GWAS); 2. those looking for much rarer, damaging variants, deemed to explain enough phenotypic variance to be considered causative. Mild phenotypes are considered most suitable for the GWAS, whilst severe phenotypes are more ideal for the latter approach. In these circumstances de novo damaging variants, which are likely to confer reproductive unfitness and are therefore heavily constrained in the general population, are typically the strongest candidates. 
GWAS studies, rather than trying to find causes of disease, attempt to isolate common genetic variants that confer increased risk. GWAS have been limited in what they have been able to reveal about the genetic architecture of epilepsy. From these studies very few variants have reached genome wide significance, and those that have explain a very small proportion of overall variance ${ }^{15}$. Hence, these studies remain of limited clinical utility. Further progress with this approach is likely to require larger numbers are participants, and possibly division of patients into phenotypic groups to reduce heterogeneity.

In contrast, studies that have employed NGS to isolate rare damaging variants in well-phenotyped individuals with severe epilepsy and/or developmental disorders have proved fruitful sources of new epilepsy-associated genes, and have provided data with genuine clinical utility. These studies have tended to approach epilepsy from two distinct angles: one angle has involved investigation of cohorts of patients with broad neurodevelopmental phenotypes which may or may not include epilepsy, the best example of which is the Deciphering Developmental Disorders (DDD) study ${ }^{16}$; the other has involved investigation of cohorts of patients specifically with epilepsy, as exemplified by the Epi4K study ${ }^{17}$. The distinction between these two approaches is important to consider because in the first epilepsy is typically reported as one of a variety of symptoms of more global neurodevelopmental disease, whereas in the latter additional features are more likely to be presented as comorbidities of the epilepsy. 


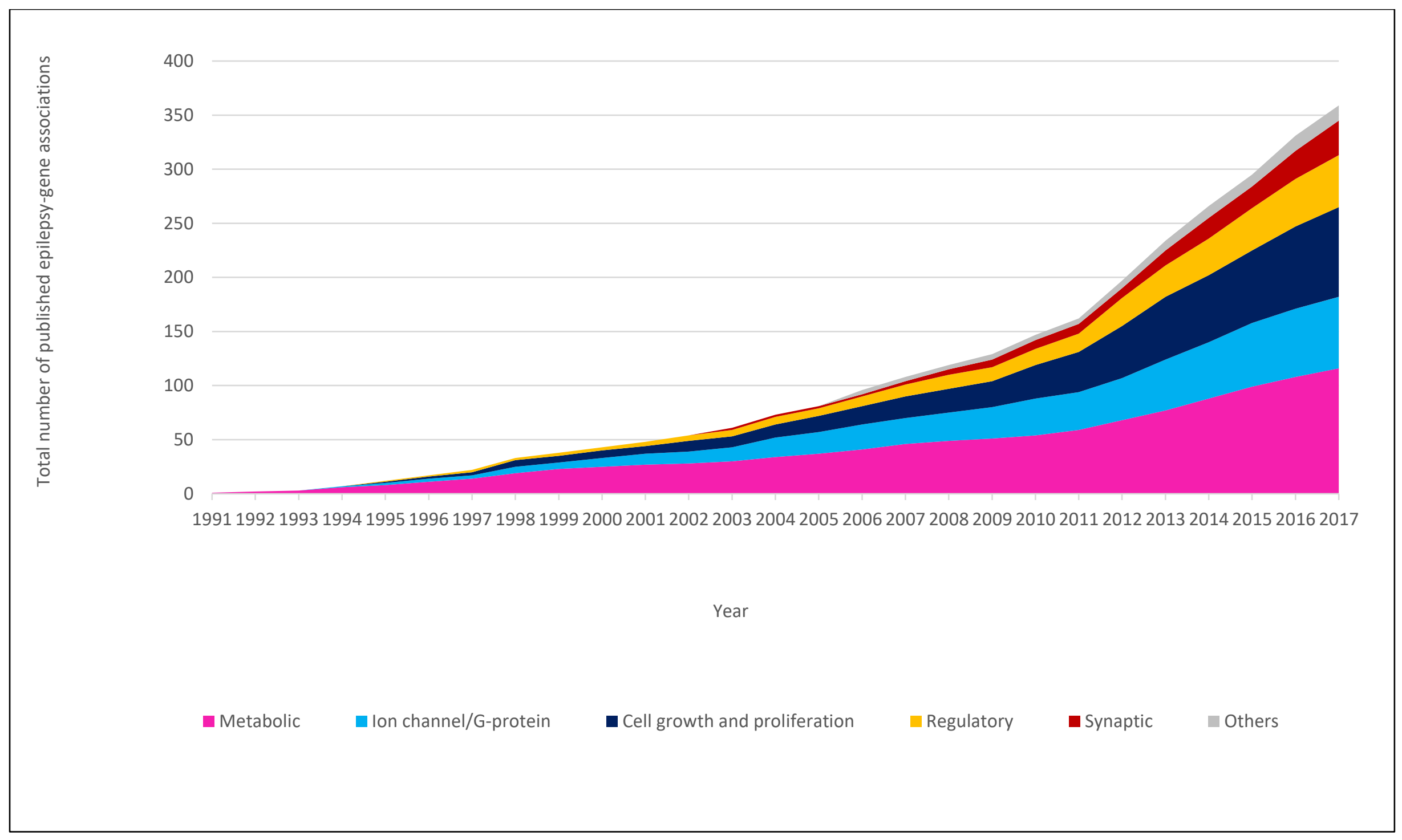

Figure 1- epilepsy gene discovery 1991-2017 
The case of STXBP1 is illustrative. De novo damaging variants in STXBP1, which encodes a protein involved in synaptic docking and fusion, were first reported in four unrelated individuals with severe early-infantile onset drug-resistant epilepsy with burst-suppression EEG pattern (Ohtahara syndrome $)^{18}$. Initially considered an "Ohtahara syndrome gene" STXBP1 emerged as an "epileptic encephalopathy gene" when further studies in different epilepsy cohorts revealed STXBP1-variants to be associated with several other severe epilepsy phenotypes including Dravet syndrome ${ }^{19}$, West syndrome ${ }^{20}$, Lennox-Gastaut syndrome ${ }^{17}$, and epilepsy with myoclonic-atonic Seizures ${ }^{21}$. Finally STXBP1 became a "developmental disorder gene" when among the first 4,293 families reported by the DDD study 11 patients with de novo damaging variants in STXBP1 were identified, all of whom had significant developmental delay, but three of whom had no history of epilepsy at all, and two more of whom only developed seizures in later childhood ${ }^{22}$.

\section{Phenotypic expansion:}

The consequence of testing large numbers of patients using platforms involving increasing numbers of genes is that the phenotypic spectrum associated with each individual genetic cause has progressively broadened. As an example, variants in SCN1A were initially considered to be associated with two distinct phenotypes: Genetic epilepsy with febrile seizures plus (GEFS+) and Dravet syndrome ${ }^{12}$. GEFS+ is a dominantly inherited familial epilepsy phenotype in which affected individuals demonstrate a predisposition to both febrile and afebrile seizures, but do not develop drug-resistant epilepsy and have good cognitive outcomes ${ }^{23}$. In contrast, in Dravet syndrome, though initial seizures are often associated with fever, a severe drug-resistant epilepsy emerges over the second and third years of life ${ }^{12}$, and this is associated with significant cognitive morbidity ${ }^{10,24}$. It is now clear that not only is there a complete spectrum of phenotypes between GEFS+ and Dravet syndrome ${ }^{25-28}$, but there are also substantially different SCN1A-associated epilepsy phenotypes that do not sit within the GEFS+/Dravet spectrum at all ${ }^{29}$. Furthermore, SCN1A variants can be associated with other neurological phenotypes which do not include epilepsy, such as familial hemiplegic migraine $(\mathrm{FHM})^{30}$. A similar picture, characterised by wide variability in epilepsy phenotypes, as well as other neurological phenotypes, has emerged for the majority of epilepsy-associated genes. Some, but not all phenotypic variability is likely to be explained by specific functional effects of the genetic variant. For example, FHM-associated SCN1A variants demonstrate gain-of-function properties ${ }^{31}$. Additional genetic and environmental modifiers are likely to explain much of the remining phenotypic variability, but these factors remain difficult to isolate and characterise.

\section{Characteristics of epilepsy-associated genes}

Among the currently known epilepsy-associated genes there is likely to be a bias in favour of those associated with severe phenotypes. This partly reflects that severely affected families may be more invested in identifying an underlying cause and hence be recruited to gene discovery studies, but it also reflects that damaging variants are easier to identify when they have arisen de novo in an individual with severe disease. Various publicly available tools are available to assess properties of candidate genes and variants. Characteristics of the majority of genes that are associated with severe epilepsies are a high relative expression in brain and a low tolerance for variation in the general population. Normative human tissue expression data comes largely from adult postmortem samples, and has been made publicly available by platforms such as the Genotype Expression Portal ${ }^{32}$. Variation tolerance information for genes comes from datasets of fully genotyped (by whole exome sequencing or whole genome sequencing) healthy individuals. The Exome Aggregation Consortium compares the number of missense observed variants in a gene with the number that would be expected based on its size and expresses this as a Z-score. A higher Z-score signifies a more intolerant gene ${ }^{33}$. In Figure 2 we have plotted the missense Z-score and relative brain expression 
from GTEx for all human genes. The 45 most commonly-implicated autosomal dominant epilepsy genes are highlighted in orange. These epilepsy-associated genes cluster in the right upper corner of Figure 2, which contains those highly brain-expressed genes which are intolerant of variation. 


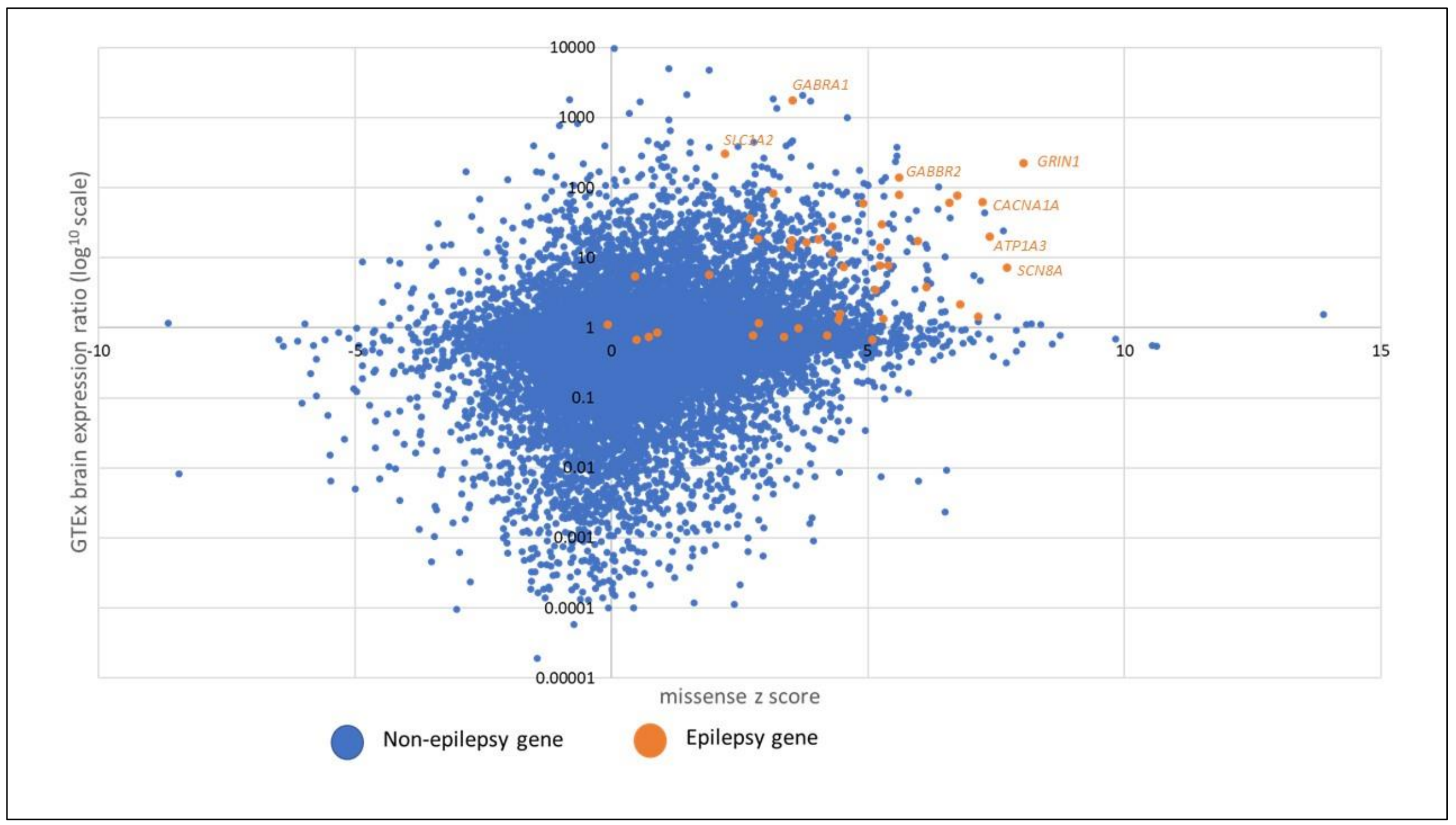

Figure 2 - relative brain expression (GTEx ratio) and missense constraint (missense Z-score) for all characterised human genes, with those 45 genes most commonly associated with dominant epilepsy highlighted orange. 
Machine-learning based computer ("in silico") tools can be used to predict likely pathogenicity of specific variants, though all have limitations ${ }^{34}$. The most useful tool for determining pathogenicity remains the identification of the same variant in an unrelated individual manifesting the same or a highly similar phenotype. The phenotypic expansion of genetic disease, and application of NGS to more mildly affected individuals is set to make variant interpretation increasingly challenging. 
Approaches to clinical genetic testing:

Single gene Sanger sequencing may still have a place in a few of the more common single gene epilepsies in which gene-phenotype correlation tends to be the rule rather than the exception. The best examples are $S C N 1 A$, which is associated with Dravet syndrome in the majority of cases, and $K C N Q 2$, which is by far the most common genetic cause of neonatal seizures ${ }^{35}$. However, the increasing affordability of NGS will make this approach decreasingly relevant. Most laboratories are now using either large gene panels, clinical exomes, or whole exomes for genetic diagnosis in epilepsy. The relative advantages and disadvantages of each approach have been reviewed elsewhere ${ }^{36}$. It must be borne in mind that in a small proportion of cases, a genetic cause for epilepsy can be established through analysis for copy number variation, using chromosomal microarray ${ }^{37-40}$, though modern NGS platforms may also be able to identify copy number variants ${ }^{41}$. Recurrently implicated CNVs linked to epilepsy include: $1 p 36$ deletion, $15 q 11.2$ deletion, $15 q 11.3$ deletion, 16p11.2 deletion, 16p13.1 deletion, and 22q11.21 deletion or duplication ${ }^{42}$.

\section{Yield from NGS testing in epilepsy:}

We identified papers reporting the application of NGS to cohorts of patients with epilepsy using a Medline literature search (date April $18^{\text {th }} 2018$ ) using the following terms:

- [epilepsy] or [epileptic] or [seizure] and

- [next generation sequencing] or [gene panel] or [exome] or [genome]

Total number of results was 870 . Abstracts of these papers were reviewed to identify studies in which NGS technology (either a targeted gene panel, a clinical exome, a whole exome, or a whole genome) had been applied in the diagnostic evaluation of a cohort of patients with epilepsy. Studies which did not include patients with epilepsy were excluded, as were those that did not report diagnostic results, or in which 10 or fewer patients were reported. 24 studies were included. The total number of diagnostic results involving each gene were summated for each paper. Between the 24 studies a total of 13,063 patients with epilepsy underwent diagnostic NGS, with 2219 positive results (17.0\%), involving variants in 210 different genes. Diagnostic yield varied markedly between studies, from $3 \%$ to $50 \%$ (Table 1 ). Diagnostic yield was associated with size of panel. Larger panels and whole exomes demonstrating significantly higher yields (Figure 3). Variation in patient selection between these studies is likely to explain much of the remaining variance. The low diagnostic yield of $4 \%$ in the study by Hildebrand et al. may be due to the fact that most of the patients in this study had sporadic temporal lobe epilepsy ${ }^{43}$. The current state of knowledge suggests that sporadic temporal lobe epilepsy is rarely monogenic. The low yield of $3 \%$ in the Myers et al. study may be because most of the patients selected had already undergone extensive genetic investigation ${ }^{44}$.

Figure 4 shows the genes recurrently implicated (four or more positive results). The most commonly implicated genes were SCN1A, KCNQ2, CDKL5, SCN2A, STXBP1, and PCDH19. These six genes were implicated in more than $50 \%$ of the diagnostic results. The 27 most commonly-implicated genes explained $80 \%$ of the diagnostic results.

Studies that recruited patients with childhood-onset severe epilepsies (e.g. Hamdan 2017; Tumienè 2017; Ko 2018) 45-47 had higher diagnostic yield than those with broader inclusion (Trump 2015; Butler 2017) ${ }^{48-49}$. Moreover, within individual studies, age of onset was also associated with increased probability of receiving a diagnostic result. In the Trump et al. study the odds ratio for a diagnostic result in the children aged less than two months was 5.0 (see Table 2 ) $^{48}$ and in Møller et al. presentation in the first month of life was associated with an odds ratio of a diagnostic result of $5.7^{50}$. Conversely in the Helbig et al. study, a significant difference for early-onset patients was not 
seen. Nor did Helbig et al. find significantly increased diagnostic yields in subgroups with infantile spasms or early onset epileptic encephalopathy ${ }^{51}$. 


\begin{tabular}{|c|c|c|c|c|}
\hline Study & Country/region & Patient selection & Platform & Yield \\
\hline Lemke $2012^{52}$ & $\begin{array}{l}\text { Germany/ } \\
\text { Switzerland }\end{array}$ & Not specified - variable phenotypes & 265 gene epilepsy panel & $16 / 33(48 \%)$ \\
\hline Kodera $2013^{53}$ & Japan & Early onset epileptic encephalopathy & 30 gene epilepsy panel & $11 / 53(21 \%)$ \\
\hline Della Mina $2014^{54}$ & Italy & Not specified - variable phenotypes & 67 gene epilepsy panel & 9/19 (47\%) \\
\hline Carvill $2014^{19}$ & Global & Infantile spasms or Lennox Gastaut Syndrome & Trio Whole Exome Sequencing (WES) & $51 / 356(14 \%)$ \\
\hline Allen $2015^{55}$ & Ireland & Unexplained early onset epileptic encephalopathy & 137 gene epilepsy panel & $13 / 50(26 \%)$ \\
\hline Trump $2015^{48}$ & UK & Tertiary referrals to Great Ormond Street Hospital & 46 gene epilepsy panel & $58 / 323(18 \%)$ \\
\hline Zhang $2015^{56}$ & China & Unexplained epilepsy and intellectual disability & 300 gene epilepsy panel & $46 / 253(18 \%)$ \\
\hline Møller $2016^{50}$ & $\begin{array}{l}\text { Denmark, Estonia, UK, } \\
\text { Argentina, Pakistan }\end{array}$ & Epileptic encephalopathies and familial epilepsies & 46 gene epilepsy panel & $49 / 216(23 \%)$ \\
\hline Myres $2016^{44}$ & Global & Unsolved epileptic encephalopathy cases & 27 candidate gene epilepsy panel & $18 / 531(3 \%)$ \\
\hline Helbig $2016^{51}$ & USA & Clinical referrals to diagnostic lab, all patients with seizures & Diagnostic exome & $119 / 314(38 \%)$ \\
\hline Zhang $2016^{57}$ & China & Early onset epileptic encephalopathy & 17 gene epilepsy panel & $56 / 175(32 \%)$ \\
\hline Parrini 2016 & Italy & Drug-resistant epilepsy (0-5 years) & 95 gene epilepsy panel & $71 / 349(20 \%)$ \\
\hline Hildebrand $2016^{43}$ & Australia & Focal epilepsy & 11 gene epilepsy panel & $11 / 251(4 \%)$ \\
\hline de Kovel $2016^{59}$ & Europe & Seizures and intellectual disability, onset $<5$ years & 26 gene epilepsy panel & $31 / 360(9 \%)$ \\
\hline Gokben $2017^{60}$ & Turkey & Early-onset epileptic encephalopathy & 16 gene panel & $9 / 30(30 \%)$ \\
\hline Butler $2017^{49}$ & USA & Clinical referrals & 110 gene epilepsy panel & $58 / 339(17 \%)$ \\
\hline Hamdan $2017^{45}$ & Canada & Developmental and epileptic encephalopathy & Trio Whole Genome Sequencing (WGS) & $63 / 197(32 \%)$ \\
\hline Ortega-Moreno $2017^{61}$ & Spain & Epilepsy and developmental delay & 106 gene epilepsy panel & $17 / 87(20 \%)$ \\
\hline Newman $2017^{62}$ & USA & Referrals to diagnostic lab. & 100 gene epilepsy panel & $36 / 166(22 \%)$ \\
\hline Tumienè $2017^{46}$ & Slovenia & Epilepsy and developmental delay or dysmorphism & Diagnostic exome (4813 genes) & $40 / 86(47 \%)$ \\
\hline Ko $2018^{47}$ & South Korea & Developmental and epileptic encephalopathy & 172 gene epilepsy panel & $97 / 278(35 \%)$ \\
\hline Palmer $2018^{63}$ & Australia & Epileptic encephalopathies & Diagnostic exome & $16 / 32(50 \%)$ \\
\hline Lindy $2018^{41}$ & USA & Clinical referrals & 70 gene panel & $1324 / 8565$ (15.5\%) \\
\hline
\end{tabular}

Table 1 - Summary of 24 NGS studies of epilepsy, involving 13,063 patients: 2012-2018 


\begin{tabular}{|l|l|l|l|l|}
\hline Study & $\begin{array}{l}\text { Clinical feature associated with } \\
\text { diagnostic result }\end{array}$ & $\begin{array}{l}\text { Number with diagnostic } \\
\text { result/Number with feature (\%) }\end{array}$ & $\begin{array}{l}\text { Number with diagnostic } \\
\text { result/Number without feature (\%) }\end{array}$ & $\begin{array}{l}\text { Odds ratio (95\% confidence intervals) and } p \\
\text { value (Fisher's exact test) }\end{array}$ \\
\hline Trump $2015^{48}$ & Presentation < 2 months & $30 / 77(39 \%)$ & $28 / 246(11 \%)$ & $5.0(2.7-9.1), p<0.0001$ \\
\hline Møller 2016 & Presentation < 1 month & $12 / 21(57 \%)$ & $37 / 195(19 \%)$ & $5.7(2.2-14.5), p<0.001$ \\
\hline Helbig $2016^{51}$ & Presentation < 1 month & $12 / 28(43 \%)$ & $107 / 276(37 \%)$ & $1.3(0.6-2.8)$, n.s. \\
\hline Helbig $2016^{51}$ & Infantile spasms & $16 / 41(39 \%)$ & $103 / 273(38 \%)$ & $1.4(0.7-2.7)$, n.s. \\
\hline Helbig $2016^{51}$ & $\begin{array}{l}\text { Early Onset Epileptic } \\
\text { Encephalopathy }\end{array}$ & $28 / 67(42 \%)$ & $91 / 247(37 \%)$ & $1.2(0.7-2.1)$, n.s. \\
\hline Ko $2018^{47}$ & Drug-resistant seizures & $74 / 161(46 \%)$ & $23 / 118(19 \%)$ & $3.5(2.0-6.1), p<0.0001$ \\
\hline
\end{tabular}

Table 1 - Odds ratios for clinical predictors of diagnostic results within epilepsy NGS studies 


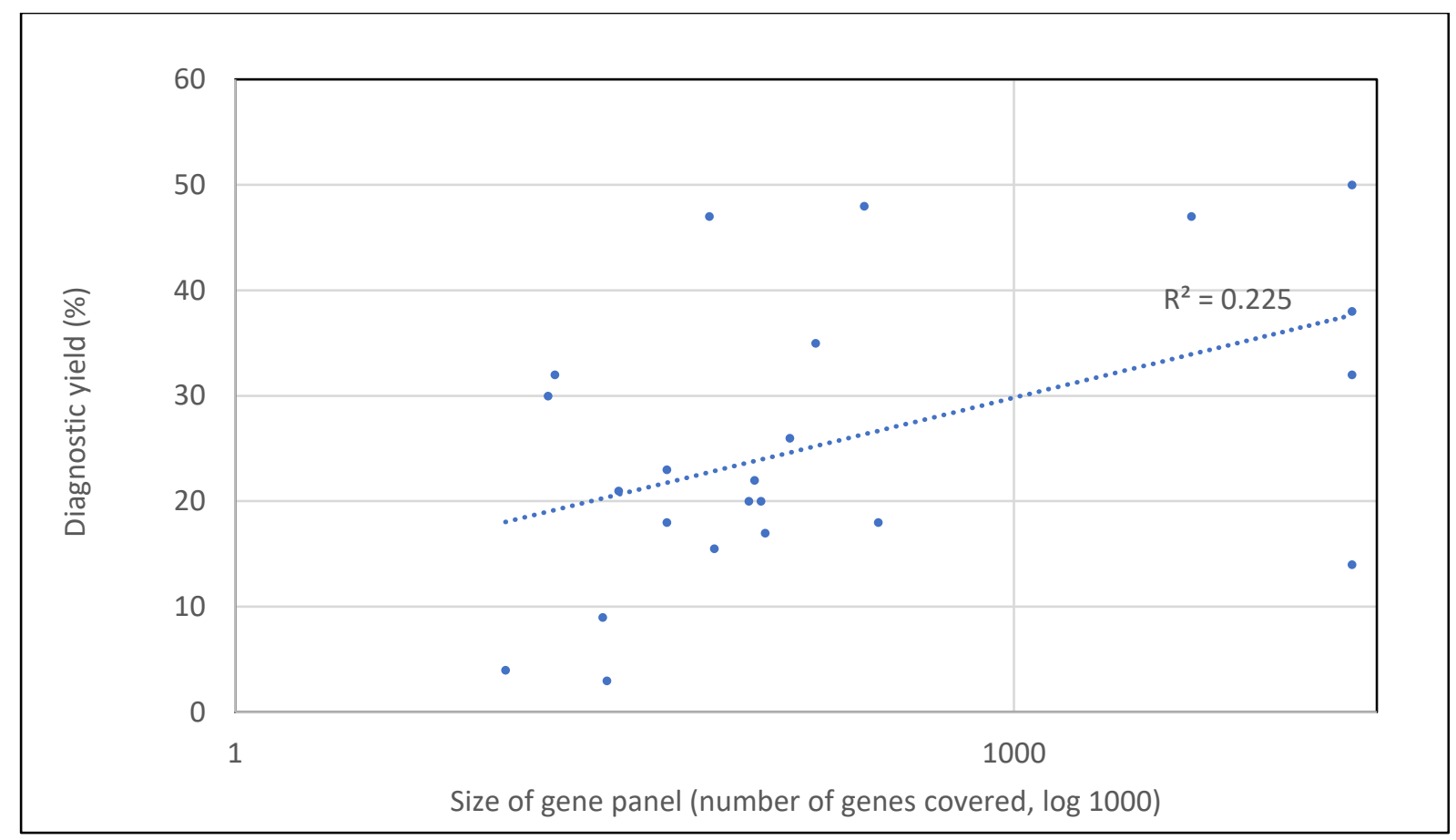

Figure 3 - relationship between size of gene panel and diagnostic yield 


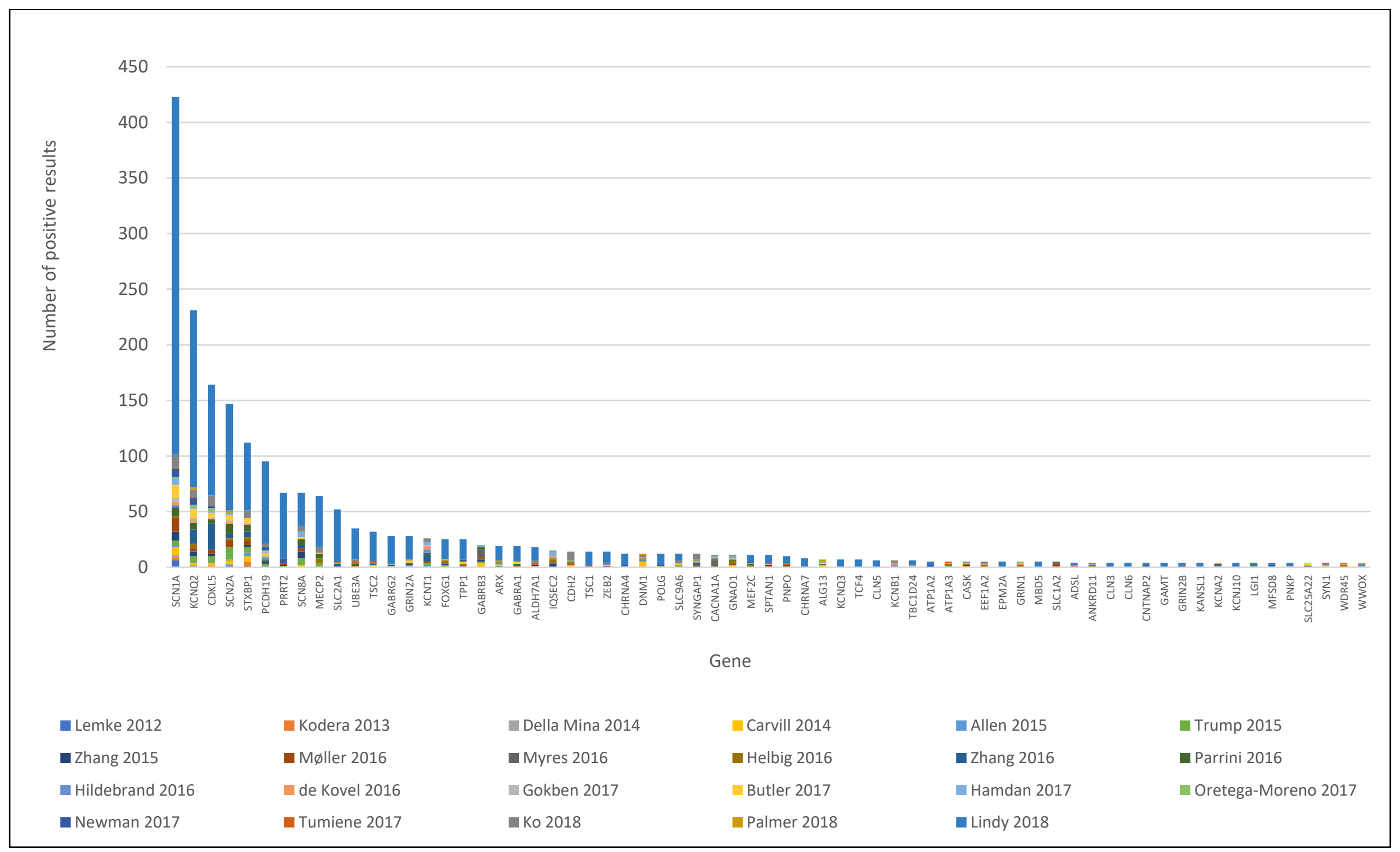

Figure 4 - Combined results from 24 NGS studies in epilepsy. Genes implicated on four or more occasions. 
The utility and impact of genetic testing in childhood epilepsy

While it is clear that genetic testing in childhood epilepsy can lead to an aetiological diagnosis in a significant proportion of children, how useful is this? For the clinician, a specific diagnosis may allow a more accurate prognosis to be given to the patient and their family, though the broadening phenotypic spectra and rarity of genetic epilepsies can render this more complex. Surveillance for longer-term health issues such as gait issues in Dravet syndrome and multi-system problems in tuberous sclerosis are also benefits of diagnosis.

How does a genetic diagnosis impact epilepsy management? There are a limited number of conditions which present with childhood epilepsy where currently a specific, aetiology-directed treatment exists. The largest group are inborn errors of metabolism, including Glut1 Deficiency and Vitamin B6 responsive disorders (Table 3). Some of these conditions may be diagnosed through blood, urine and CSF investigations rather than genetic testing. However children with Glut1 deficiency may present with seizures alone and may not have raised enough clinical suspicion to undergo lumbar puncture and CSF glucose testing ${ }^{35}$.

There are a number of experimental therapies which have been used in in vitro studies or in a small number of patients (Table 4). AN example is Quinidine for KCNT1-related epilepsies. Following successful blockade of abnormal potassium current in vitro, initial clinical reports were promising. However, a randomised controlled trial failed to show benefit ${ }^{64}$ and in the largest case series published to date only $20 \%$ of patients showed a $>50 \%$ seizure reduction in seizure frequency. However, in rare devastating disorders such as KCNT1-related epilepsies where seizures are unrelenting, clinicians will often consider a therapeutic trial.

The major impact of a genetic diagnosis on clinical management is usually choosing or avoiding certain antiepileptic medications (Table 4). Several studies have examined how a specific genetic diagnosis influenced management. Truty et al. reported an unselected, mostly paediatric cohort of over 9000 patients referred for epilepsy gene panel testing ${ }^{65} .33 \%$ of the 1502 patients with a positive molecular genetic diagnosis had a variant which was "actionable". The authors categorised these actionable diagnoses into biochemical disorders, such as Glut1 deficiency and neuronal ceroid lipofuscinosis type 2 (CLN2), and indications or contraindications for anti-epileptic drugs (AEDs). Over $50 \%$ of the actionable findings related to avoidance of contraindicated AEDs, primarily sodium channel blockers in SCN1A-related epilepsies. $40 \%$ of actionable findings related to positive AED selection. While these findings are encouraging for a precision medicine approach, the authors acknowledge that in many cases supportive evidence is limited. For example, Memantine, a NMDAR blocker, is listed as an "emerging" treatment for the treatment of GRIN2A-related disorders. However GRIN2A variants can be both loss or gain of function, and whilst some phenotype:genotype correlation has been demonstrated ${ }^{66}$, in the absence of in vitro functional testing, it may not be possible to determine whether a patient will benefit or be harmed by NMDAR blockade.

Another positive benefit of a genetic diagnosis is identifying patients eligible for clinical trials. In the Truty et al. study this applied to $25 \%$ of those with a positive molecular diagnosis ${ }^{65}$. Another study examined the impact of whole exome sequencing in 180 patients with epilepsy of unknown cause with onset under 5 years of age ${ }^{67}$. A molecular genetic diagnosis had clinical implications in 27 of 59 diagnosed patients and led to a change in management in 23 patients (39\%) or $13 \%$ of all patients. This ranged from choice or avoidance of specific medications to limiting of investigations and stopping medication in SCN2A and KCNQ2-related self-limited familial neonatal/infantile epilepsies. 
Oates et al. found clinically actionable variants in $63 \%$ of positive diagnoses on a targeted NGS epilepsy panel, again largely related to recommendations about sodium channel blocking AEDs ${ }^{68}$. In a prospective, population-based study of epilepsy of onset under 3 years, $64 / 80(80 \%)$ of the genetic diagnoses were stated to have potential treatment implications ${ }^{35}$. The authors acknowledged that much of this is based on limited quality evidence. However both Stiripentol and Cannabidiol have been tested in randomised controlled trials of Dravet syndrome.

\begin{tabular}{|c|c|c|c|}
\hline Gene & $\begin{array}{l}\text { AEDs/treatments } \\
\text { which are } \\
\text { recommended }\end{array}$ & AED to avoid & $\begin{array}{l}\text { Other management } \\
\text { implications }\end{array}$ \\
\hline$S L C 2 A 1$ & Ketogenic Diet & Phenobarbitone & \\
\hline$A L D H 7 A 1$ & Pyridoxine & - & Lysine-restricted diet \\
\hline$P N P O$ & Pyridoxal phosphate & - & \\
\hline GAMT & $\begin{array}{l}\text { Oral creatine } \\
\text { supplements }\end{array}$ & - & \\
\hline SLC6A8 & $\begin{array}{l}\text { Oral creatine } \\
\text { supplements }\end{array}$ & - & \\
\hline TPP1 (CLN2) & $\begin{array}{l}\text { Tripeptidyl-peptidase I } \\
\text { enzyme replacement } \\
\text { therapy }\end{array}$ & - & - \\
\hline FOLR1 & Folinic acid & - & - \\
\hline SLC35A2 & $\begin{array}{l}\text { Galactose } \\
\text { supplements }\end{array}$ & - & \\
\hline
\end{tabular}

Table 3: Therapeutic implications in metabolic disorders presenting with severe childhood epilepsy which may be diagnosed by genetic testing. Biotinidase deficiency is not included as this is usually diagnosed by low blood biotinidase activity rather than genetic testing

\begin{tabular}{|l|l|l|l|}
\hline Gene & $\begin{array}{l}\text { AEDs/treatments which } \\
\text { are recommended }\end{array}$ & AED to avoid & $\begin{array}{l}\text { Other management } \\
\text { implications }\end{array}$ \\
\hline SCN1A & $\begin{array}{l}\text { Stiripentol, valproate, } \\
\text { clobazam } \\
\text { Ketogenic Diet } \\
\text { Cannabidiol } \\
\text { Fenfluramine }\end{array}$ & Carbamazepine/Lamotrigine & \\
\hline SCN2A* & Carbamazepine, phenytoin & - & $\begin{array}{l}\text { Consider high-dose } \\
\text { intravenous phenytoin } \\
\text { for status epilepticus }\end{array}$ \\
\hline SCN8A & Carbamazepine, phenytoin & - & - \\
\hline KCNQ2 & Carbamazepine, phenytoin & - & - \\
\hline POLG & - & Sodium valproate & - \\
\hline PCDH19 & Clobazam & - & - \\
\hline PRRT2 & Carbamazepine & - & - \\
\hline KCNT1 & $\begin{array}{l}\text { Trial of Quinidine in early } \\
\text { onset seizures } \\
\text { Potassium bromides } \\
\text { Ketogenic Diet }\end{array}$ & - & - \\
\hline TSC1/TSC2 & $\begin{array}{l}\text { Vigabatrin for infantile } \\
\text { spasms }\end{array}$ & & $\begin{array}{l}\text { Surveillance for multi- } \\
\text { system features }\end{array}$ \\
\hline
\end{tabular}




\begin{tabular}{|l|l|l|l|}
\hline & & & $\begin{array}{l}\text { Emerging use of } \\
\text { Everolimus and MTOR } \\
\text { inhibitors }\end{array}$ \\
\hline ATP1A3 & Flunarizine & - & - \\
\hline
\end{tabular}

Table 4: Current therapeutic implications of genes which are commonly implicated in childhood epilepsy. *the majority of SCN2A-related epileptic encephalopathy variants with seizure onset $<3$ months are gain of function

Achieving a genetic diagnosis is likely to limit the diagnostic odyssey and potentially avoid further invasive tests such as muscle biopsy. While it can be difficult to fully appraise such effects due to differences between healthcare systems, referral patterns, and funding systems, several groups have shown that earlier genetic testing is cost-effective and leads to earlier diagnosis ${ }^{63,69}$. Retrospective analysis of clinical data in one study found that earlier use of the NGS panel could have potentially reduced investigations by two-thirds and the median diagnostic delay from 3.43 years to 21 days ${ }^{68}$. In a different healthcare setting where WES testing was restricted, four patients had lengthy diagnostic journeys ranging from one to eight years which were finally ended by a diagnostic WES result ${ }^{70}$. The authors delineated the three costs of the diagnostic journey: cost of time lost to the patient/family; impact quality of life; and monetary cost. This study highlighted an important aspect of making a genetic diagnosis in childhood epilepsy; the opportunity to give a definitive diagnosis. This is important to families. Receiving a diagnosis and the diagnostic journey were important themes in the Sussex Early Epilepsy and Neurobehavior (SEEN) study of parental experience of childhood epilepsy. However, specific studies of the impact if genetic diagnoses for childhood epilepsy are limited. In a study of children with Dravet syndrome, $87 \%$ of caregivers reported that the diagnosis itself was helpful and $61 \%$ reported that it led to increased access to therapies ${ }^{71}$. When requesting genetic tests, it is important to understand the expectations and the perspectives of the parents regarding possible outcomes and implications. Many parents carry feelings of guilt for their child's epilepsy and this can be relieved or worsened by a genetic diagnosis, particularly if they are a carrier $^{72}$.

As the majority of causative variants in the severe epilepsies are de novo, clinicians will usually give a low recurrence risk of approximately $1 \%$, taking into account the possibility of germline mosaicism. However, it is increasingly recognised that there may be more significant levels of parental somatic mosaicism, even when parents are unaffected. This has been demonstrated in SCN1A, SCN8A and KCNQ2-related epilepsies ${ }^{73-73}$. The presence of parental mosaicism can increase the risk of recurrence up to $50 \%$, depending on the level of mosaicism detected. It is vital that families have access to both expert genetic counselling and clinicians experienced in epilepsy genetics. A further advantage of genetic diagnosis can be to afford access to specific support groups for patients and their families.

\section{Conclusion and Future Directions:}

It is clear that genetic testing should be considered a first-line investigation for patients presenting with epilepsy, particularly where it is early onset, resistant to treatment and associated with other neurodevelopmental disorders. The yield of genetic diagnosis by NGS techniques is significant and can have management implications in addition to allowing genetic counselling. As we move away from NGS panels and towards clinical whole genome sequencing, identification of non-coding variants may provide insight into the $20-50 \%$ of patients who do not receive a diagnosis by NGS panel or whole exome sequencing. Innovative treatments directed at the genetic aetiology such as gene therapy are currently undergoing pre-clinical studies. It is therefore vital that as well as continuing to increase the yield of genetic testing, we understand the natural history of the genetic epilepsies of childhood by undertaking prospective evaluations of epilepsy and developmental 
phenotypes. This will better equip us to assess the impact of the personalised medicine which is on the horizon.

\section{References:}

1. Vadlamudi L, Andermann E, Lombroso CT, Schachter SC, Milne RL, Hopper JL, Andermann F \& Berkovic SF, 2004. Epilepsy in twins: insights from unique historical data of William Lennox. Neurology; 62: 127-1133.

2. Kjeldsen MJ, Corey LA, Solaas MH, Friis ML, Harris JR, Kyvik KO, Christensen K \& Pellock JM, 2005. Genetic factors in seizures: a population-based study of 47,626 US, Norwegian and Danish twin pairs. Twin Research \& Human Genetics; 8: 138-147.

3. Webb DW, Fryer AE \& Osborne JP, 1991. On the incidence of fits and mental retardation in tuberous sclerosis. Journal of Medical Genetics; 28: 395-397.

4. Berry-Kravis E, Raspa M, Loggin-Hester L, Bishop E, Holiday D \& Bailey DB, 2010. Seizures in fragile X syndrome: characteristics and comorbid diagnoses. American Journal on Intellectual \& Developmental Disabilities; 115: 461-472.

5. Mudigoudar B, Nune S, Fulton S, Dayyat E \& Wheless JW, 2017. Epilepsy in 22q11.2 deletion Mullen SA, Carvill GL, Bellows S, Bayly MA, Berkovic SF, Dibbens LM, Scheffer IE \& Mefford $\mathrm{HC}$, 2013. Copy number variants are frequent in genetic generalized epilepsy with intellectual disability. Neurology; 81: 1507-1514.

6. Pelc K, Boyd SG, Cheron G \& Dan B. 2008, Epilepsy in Angelman syndrome. Seizure; 17: 211217

7. Steinlein OK, Mulley JC, Propping P, Wallace RH, Phillips HA, Sutherland GR, Scheffer IE \& Berkovic SF, 1995. A missense mutation in the neuronal nicotinic acetylcholine receptor alpha 4 subunit is associated with autosomal dominant nocturnal frontal lobe epilepsy. Nature Genetics; 11:201-203.

8. Scheffer IE, Bhatia KP, Lopes-Cendes I, Fish DR, Marsden CD, et al., 1995. Autosomal dominant nocturnal frontal lobe epilepsy. A distinctive clinical disorder. Brain; 118: 61-73.

9. Claes L, Del-Favero J, Ceulemans B, Lagae L, van Broeckhoven C \& de Jonghe P, 2001. De novo mutations in the sodium-channel gene SCN1A cause severe myoclonic epilepsy of infancy. American Journal of Human Genetics; 68:1327-1332.

10. Dravet $C$ 2012. How Dravet syndrome became a model for studying childhood genetic epilepsies. Brain; 135: 2309-2311.

11. Depienne C, Trouillard O, Saint-Martin C, Gourfinkel-An I, Bouteiller D, et al., 2009. Spectrum of SCN1A gene mutations associated with Dravet syndrome: analysis of 333 patients. Journal of Medical Genetics; 46: 183-191.

12. Brunklaus A, Ellis R, Reavey E, Forbes GH \& Zuberi SM, 2012. Prognostic, clinical and demographic features in SCN1A mutation-positive Dravet syndrome. Brain; 135: 2329-2336.

13. Biervert C, Schroeder BC, Kubisch C, Berkovic SF, Propping P et al., 1998. A potassium channel mutation in neonatal human epilepsy. Science; 279: 403-406.

14. Schroeder BC, Kubisch C, Stein V, \& Jentsch TJ, 1998. Moderate loss of function of cyclicAMP-modulated KCNQ2/KCNQ3 K+ channels causes epilepsy. Nature; 396: 687-690.

15. Abou-Khalil B, Auce P, Avbersek A, Bahlo M, Balding DJ, 2018. Genome-wide mega-analysis identifies 16 loci and highlights diverse biological mechanisms in the common epilepsies. Nature Communications; 9: 5269.

16. McRae JF, Clayton S, Fitzgerald TW, Kaplanis J, Prigmore E, et al., 2017. Prevalence and architecture of De novo mutations in developmental disorders. Nature; 542: 433. 
17. Allen AS, Berkovic SF, Cossette P, Delanty N, Dlugos D, et al., 2013. De novo mutations in epileptic encephalopathies. Nature; 501: 217-221.

18. Saitsu H, Kato M, Mizuguchi T, Hamada K, Osaka H, et al., 2008. De novo mutations in the gene encoding STXBP1 (MUNC18-1) cause early infantile epileptic encephalopathy. Nature Genetics; 40: 782-788.

19. Carvill GL, Weckhuysen S, McMahon JM, Hartmann C, Moller RS, et al., 2014. GABRA1 and STXBP1: novel genetic causes of Dravet syndrome. Neurology; 82: 1245-1253.

20. Michaud JL, Lachance M, Hamdan FF, Carmant L, Lortie A, et al., 2014. The genetic landscape of infantile spasms. Human Molecular Genetics; 23: 4846-4858.

21. Vlaskamp DRM, Rump P, Callenbach PMC, Vos YJ, Sikkema-Raddatz B, van Ravenswaaij-Arts CMA \& Brouwer OF, 2016. Haploinsufficiency of the STX1B gene is associated with myoclonic astatic epilepsy. European Journal of Paediatric Neurology; 20: 489-492.

22. Suri M, Evers JMG, Laskowski RA, O'Brien S, Baker K, et al., 2017. Protein structure and phenotypic analysis of pathogenic and population missense variants in STXBP1. Molecular Genetics \& Genomic Medicine; 5: 495-507.

23. Scheffer IE \& Berkovic SF, 1997. Generalized epilepsy with febrile seizures plus. A genetic disorder with heterogeneous clinical phenotypes. Brain; 120: 479-490.

24. Dravet C 1978. Les épilepsies graves de l'enfant. Vie Medicale; 8: 543-548.

25. Fukuma G, Oguni $H$, Shirasaka $Y$, Watanabe K, Miyajima T, et al., 2004. Mutations of neuronal voltage-gated $\mathrm{Na}+$ channel alpha 1 subunit gene SCN1A in core severe myoclonic epilepsy in infancy (SMEI) and in borderline SMEI (SMEB). Epilepsia; 45: 140-148.

26. Kanai K, Hirose S, Oguni H, Fukuma G, Shirasaka Y, et al., 2004. Effect of localization of missense mutations in SCN1A on epilepsy phenotype severity. Neurology; 63: 329-334.

27. Harkin LA, McMahon JM, lona X, Dibbens L, Pelekanos JT, et al., 2007. The spectrum of SCN1A-related infantile epileptic encephalopathies. Brain; 130: 843-852.

28. Myers KA, Burgess R, Afawi Z, Damiano JA, Berkovic SF, Hildebrand MS \& Scheffer IE, 2017b. De novo SCN1A pathogenic variants in the GEFS+ spectrum: Not always a familial syndrome. Epilepsia; 58: e26-e30.

29. Sadleir LG, Mountier El, Gill D, Davis S, Joshi C, et al., 2017. Not all SCN1A epileptic encephalopathies are Dravet syndrome: Early profound Thr226Met phenotype. Neurology; 89:1035-1042.

30. Dichgans M, Freilinger T, Eckstein G, Babini E, Lorenz-Depiereux B, et al., 2005 Mutation in the neuronal voltage-gated sodium channel SCN1A in familial hemiplegic migraine. The Lancet; 366: 371-377.

31. Dhifallah S, Lancaster E, Merrill S, Leroudier N, Mantegazza M \& Cestèle S, 2018. Gain of function for the SCN1A/hNav1.1-L1670W mutation responsible for familial hemiplegic migraine. Frontiers in Molecular Neuroscience; 11: 232.

32. Aguet F, Ardlie KG, Cumming BB, Gelfand ET, Getz G et al. 2017. Genetic effects on gene expression across human tissues. Nature; 550: 204.

33. Lek M, Karczewski KJ, Minikel EV, Samocha KE, Banks E, et al., 2016. Analysis of proteincoding genetic variation in 60,706 humans. Nature; 536: 285.

34. Salgado D, Bellgard MI, Desvignes J \& Béroud C, 2016. How to identify pathogenic mutations among all those variations: variant annotation and filtration in the genome sequencing era. Human Mutation; 37: 1272-1282.

35. Symonds JD, Zuberi SM, Stewart K, McLellan A, O'Regan M, et al., 2019. Incidence and phenotypes of childhood-onset genetic epilepsies: a prospective population-based national cohort. Brain; 142: 2303-2318. 
36. Sun $Y$, Ruivenkamp CAL, Hoffer MJV, Vrijenhoek T, Kriek M, van Asperen CJ, den Dunnen JT \& Santen GWE, 2015. Next-generation diagnostics: gene panel, exome, or whole genome? Human Mutation; 36: 648-655.

37. Mefford HC, Muhle H, Ostertag P, von Spiczak S, Buysse K, et al., 2010. Genome-wide copy number variation in epilepsy: novel susceptibility loci in idiopathic generalized and focal epilepsies. PLoS Genetics; 6: e1000962.

38. Mefford HC, Yendle SC, Hsu C, Cook J, Geraghty E, et al., 2011. Rare copy number variants are an important cause of epileptic encephalopathies. Annals of Neurology; 70: 974-985.

39. Olson H, Shen Y, Avallone J, Sheidley BR, Pinsky R, et al., 2014. Copy number variation plays an important role in clinical epilepsy. Annals of Neurology; 75: 943-958.

40. Mullen SA, Carvill GL, Bellows S, Bayly MA, Berkovic SF, Dibbens LM, Scheffer IE \& Mefford $H C$, 2013. Copy number variants are frequent in genetic generalized epilepsy with intellectual disability. Neurology; 81: 1507-1514.

41. Lindy AS, Stosser MB, Bulter E, Downtain-Pickersgill C, Shanmugham A, et al., 2018. Diagnostic outcomes for genetic testing of 70 genes in 8565 patients with epilepsy and neurodevelopmental disorders. Epilepsia; 59: 1062-1071.

42. Coppola A, Cellini E, Stamberger H, Saarentaus E, Cetica V, et al., 2019. Diagnostic implications of genetic copy number variation in epilepsy plus. Epilepsia; 60: 689-706.

43. Hildebrand MS, Myers CT, Carvill GL, Regan BM, Damiano JA, et al., 2016. A targeted resequencing gene panel for focal epilepsy. Neurology; 86: 1605-1612.

44. Myers C, McMahon J, Schneider A, Petrovski S, Allen A, et al., 2016. De novo mutations in SLC1A2 and CACNA1A are important causes of epileptic encephalopathies. The American Journal of Human Genetics; 99: 287-298.

45. Hamdan FF, Myers CT, Cossette P, Lemay P, Spiegelman D, et al., 2017. High rate of recurrent De novo mutations in developmental and epileptic encephalopathies. The American Journal of Human Genetics; 101: 664-685.

46. Tumienè B, Maver A, Writzl K, Hodžić A, Čuturilo G, Kuzmanić-Šamija R, Čulić V \& Peterlin B 2017. Diagnostic exome sequencing of syndromic epilepsy patients in clinical practice. Clinical Genetics; 93: 1057-1062

47. Ko A, Youn SE, Kim SH, Lee JS, Kim S, et al., 2018. Targeted gene panel and genotypephenotype correlation in children with developmental and epileptic encephalopathy. Epilepsy Research; 141: 48-55.

48. Trump N, McTague A, Brittain H, Papandreou A, Meyer E, et al., 2016. Improving diagnosis and broadening the phenotypes in early-onset seizure and severe developmental delay disorders through gene panel analysis. Journal of Medical Genetics; 53: 310-317.

49. Butler KM, da Silva C, Alexander JJ, Hegde M \& Escayg A, 2017. Diagnostic yield from 339 epilepsy patients screened on a clinical gene panel. Pediatric Neurology; 77: 61-66.

50. Møller RS, Larsen LHG, Johannesen KM, Talvik I, Talvik T, et al., 2016. Gene panel testing in epileptic encephalopathies and familial epilepsies. Molecular Syndromology; 7: 210-219.

51. Helbig KL, Farwell Hagman KD, Shinde DN, Mroske C, Powis Z, Li S, Tang S \& Helbig I, 2016. Diagnostic exome sequencing provides a molecular diagnosis for a significant proportion of patients with epilepsy. Genetics In Medicine; 18: 898-905.

52. Lemke JR, Riesch E, Scheurenbrand T, Schubach M, Wilhelm C, et al., 2012. Targeted next generation sequencing as a diagnostic tool in epileptic disorders. Epilepsia; 53: 1387-1398.

53. Kodera H, Kato M, Nord AS, Walsh T, Lee M, et al., 2013. Targeted capture and sequencing for detection of mutations causing early onset epileptic encephalopathy. Epilepsia; 54: 12621269. 
54. Della Mina E, Ciccone R, Brustia F, Bayindir B, Limongelli I, et al., 2015. Improving molecular diagnosis in epilepsy by a dedicated high-throughput sequencing platform. European Journal of Human Genetics; 23:354-362.

55. Allen, NM, Conroy J, Shawhan A, Lynch B, Correa RG et al., 2016. Unexplained early onset epileptic encephalopathy: Exome screening and phenotype expansion. Epilepsia; 57: e12e17.

56. Zhang Y, Kong W, Gao Y, Liu X, Gao K, et al., 2015. Gene Mutation analysis in 253 chinese children with unexplained epilepsy and intellectual/developmental disabilities. PLOS ONE; 10: e0141782.

57. Zhang Q, Li J, Zhao Y, Bao X, Wei L \& Wang J, 2017. Gene mutation analysis of 175 Chinese patients with early-onset epileptic encephalopathy. Clinical Genetics; 91: 717-724.

58. Parrini E, Marini C, Mei D, Galuppi A, Cellini E, et al., 2017. Diagnostic targeted resequencing in 349 patients with drug-resistant pediatric epilepsies identifies causative mutations in 30 different genes. Human Mutation; 38:216-225.

59. Kovel CG, Brilstra EH, Kempen MJ, Ruben S, Nijman IJ, et al., 2016. Targeted sequencing of 351 candidate genes for epileptic encephalopathy in a large cohort of patients. Molecular Genetics \& Genomic Medicine; 4: 568-580.

60. Gokben S, Onay H, Yilmaz S, Atik T, Serdaroglu G, Tekin H \& Ozkinay F, 2017. Targeted next generation sequencing: the diagnostic value in early-onset epileptic encephalopathy. Acta Neurologica Belgica; 117: 131-138.

61. Ortega-Moreno L, Giráldez BG, Soto-Insuga V, Losada-Del Pozo R, Rodrigo-Moreno Met al., 2017. Molecular diagnosis of patients with epilepsy and developmental delay using a customized panel of epilepsy genes. PLOS ONE; 12: e0188978.

62. Newman H, Powis Z, Yussuf A \& Wang J, 2017. Phenotype is not always a positive predictor of detection rate in epilepsy panels (P1.231). Neurology; 88: 16.

63. Palmer EE, Schofield D, Shrestha, Kandula T, Macintosh R, et al., 2018. Integrating exome sequencing into a diagnostic pathway for epileptic encephalopathy: Evidence of clinical utility and cost effectiveness. Molecular Genetics \& Genomic Medicine; 6:186-199.

64. Mullen SA, Carney PW, Roten A, Ching M, Lightfoot PA, et al., 2018. Precision therapy for epilepsy due to KCNT1 mutations. Neurology; 90: e67.

65. Truty R, Patil N, Sankar R, Sullivan J, Millichap J, et al., 2019. Possible precision medicine implications from genetic testing using combined detection of sequence and intragenic copy number variants in a large cohort with childhood epilepsy. Epilepsia Open; 4: 397-408.

66. Strehlow V, Heyne HO, Vlaskamp DRM, Marwick KFM, Rudolf G, et al., 2019. GRIN2A-related disorders: genotype and functional consequence predict phenotype. Brain; 142: 80-92.

67. Demos M, Guella I, DeGuzman C, McKenzie MB, Buerki SE, et al., 2019. Diagnostic Yield and Treatment Impact of Targeted Exome Sequencing in Early-Onset Epilepsy. Frontiers in Neurology; 10: 434.

68. Oates S, Tang S, Rosch R, Lear R, Hughes EF, et al., 2018. Incorporating epilepsy genetics into clinical practice: a $360^{\circ}$ evaluation. NPJ Genomic Medicine; 10: 13.

69. Howell KB, Eggers S, Dalziel K, Riseley J, Mandelstam S, et al., 2018. A population-based costeffectiveness study of early genetic testing in severe epilepsies of infancy. Epilepsia; 59: 1177-1187

70. Joshi C, Kolbe DL, Mansilla MA, Mason SO, Smith RJ, \& Campbell CA, 2016. Reducing the cost of the diagnostic odyssey in early onset epileptic encephalopathies. Biomedical Reseach International; 6421039.

71. Brunklaus A, Dorris L, Ellis R, Reavey E, Lee E, et al., 2013. The clinical utility of an SCN1A genetic diagnosis in infantile-onset epilepsy. Developmental Medicine \& Child Neurology; 55: 154-161. 
72. Jaitovich Groisman I, Hurlimann T, \& Godard B, 2019. Parents of a child with epilepsy: Views and expectations on receiving genetic results from Whole Genome Sequencing. Epilepsy \& Behavior; 90: 178-190.

73. Myers CT, Hollingsworth G, Muir AM, Schneider AL, Thuesmunn Z, et al., 2018. Parental mosaicism in "de novo" epileptic encephalopathies. New England Journal of Medicine; 378: 1646-1648.

74. Møller RS, Liebmann N, Larsen LHG, Stiller M, Hentschel J, et al., 2019. Parental mosaicism in epilepsies due to alleged de novo variants. Epilepsia; 60: e63-e66. 
